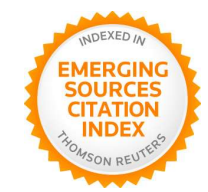

\title{
Learning technologies and EFL teamwork
}

\author{
Soraya García-Sánchez ${ }^{1}$ \\ Universidad de Las Palmas de Gran Canaria
}

Nicholas C. Burbules

University of Illinois

\begin{abstract}
In this article, we discuss how technology-based learning methodologies developed in primary and secondary education can offer useful approaches to higher education instruction. For example, young and adult Spanish speakers are often used to participating in discussions and debates in their English as a Foreign Language (EFL) courses. This paper highlights how this model can help support a wider collaborative, ubiquitous learning environment that supports in-class and out-of-class interactions that allow $21^{\text {st }}$ century second-language learners to work with other peers in building (digital) knowledge and forming stronger arguments in English. This article emphasizes that mastering communication skills, cooperation, and collaboration through a combination of learning technologies are themselves necessary $21^{\text {st }}$ century skills in today's citizens. These capabilities can help to establish a continuous lifelong learning orientation when dealing with education at different stages of life. We will conclude that higher education assessment strategies need to be transformed in order to appreciate these collaborative, digital and EFL students' outcomes.
\end{abstract}

Keywords: cooperation, collaboration, EFL, learning technologies, ubiquitous learning

\section{RESUMEN}

Corresponding author - Universidad de Las Palmas de Gran Canaria, Departamento de Lenguas Modernas, Gran Canaria (Spain). Email: soraya.garcia@ulpgc.es 
En este trabajo se establece que una metodología de aprendizaje sólida que se apoya de la tecnología en educación primaria y secundaria puede ofrecer fórmulas útiles de aprendizaje a los estudiantes de educación superior. Por ejemplo, los jóvenes y adultos españoles están acostumbrados a participar en foros de debate durante sus cursos de Inglés como Lengua Extranjera (ILE). Este trabajo subraya cómo un ambiente de aprendizaje ubicuo que promueve interacción dentro y fuera del aula es el contexto que necesitan estos estudiantes del siglo XXI para trabajar con otros compañeros a través de la creación del conocimiento (digital) y a través de la exposición de argumentos y opiniones en lengua inglesa. Este artículo señala que el desarrollo de las habilidades comunicativas, la cooperación, y la colaboración a través de las tecnologías del aprendizaje son habilidades necesarias para el ciudadano del siglo XXI. Estas habilidades pueden ayudar a establecer una continua orientación de aprendizaje a lo largo de la vida cuando se aborda la educación desde sus distintas etapas. Como consecuencia de ello, concluiremos argumentando que la educación superior necesita también transformar su sistema de evaluación para poder medir estos resultados comunicativos, colaborativos y digitales de los estudiantes de ILE.

Palabras clave: cooperación, ILE, colaboración, tecnología, aprendizaje ubicuo

\section{Introduction}

Implementing e-collaboration and group tasks can improve English as a Foreign Language (EFL) students' motivation. Learners can build up confidence and work together by using digital tools, by exercising cognitive and metacognitive skills, and by acquiring the additional skills and resources that would allow them to complete these group tasks successfully (Kim \& Pekrun, 2014; Liu, 2014; Sears \& Pai, 2013). This learning process entails using the English language in almost all its dimensions: listening, speaking, reading, writing, and mastering new vocabularies. In addition to these verbal and nonverbal communication strategies, designing appropriate e-collaborative tasks involves an appreciation of the affordances, and the limitations, of the Information and Communication Technologies (ICTs) being used.

Higher education learners around the world are aware of the positive implications of speaking English, particularly in their professional lives, as $21^{\text {st }}$ century citizens. There is, however, some apprehension about speaking the language due to a lack of practical communicative encounters or past negative experiences. For this reason, collaborative learning is presented as one pedagogical approach that can build up students' confidence when speaking the language inside and outside the classroom, or when writing down observations on a virtual learning platform (VLP). An e-collaborative learning environment invites in-class, out-of-class and ubiquitous digital interactions using mobile devices that allow participants to have online communicative interactions, access to content, and learning activities while on the go. Using internet-based mobile applications for learning purposes involves that 
learning has become a ubiquitous practice that may happen anywhere and anytime (Burbules, 2012, 2013, 2014; Cope \& Kalantzis, 2009; García-Sánchez, 2014; Peng et al., 2004).

Different modes of collaboration with other peers is one scenario that can be provided for EFL tertiary learners with the intention of enhancing their communicative skills not only in face-to-face situations, which are more often formal, professional-oriented and academic, but also outside the educational buildings, which allows learners to develop communicative interaction skills within other specialized or informal learning settings (Burbules, 2012; Kalantzis \& Cope, 2012; Ogata \& Uosaki, 2012). By promoting a range of EFL interactions, cooperation and collaboration provide Spanish higher education learners with some of the most essential $21^{\text {st }}$ century skills for the present and the future workplace. This paper, therefore, focuses on encouraging the e-collaborative learning tasks that can improve these students' EFL skills; and to suggest ways in which they can be assessed following a set of self-assessment and peer-topeer criteria.

\section{Theoretical background}

The key notions proposed in this research correspond with $21^{\text {st }}$ century skills that enhance ICT abilities, interaction and communication among the EFL educational community by means of self-study, group work, technology, and the internet. First, a ubiquitous learning environment (ULE) allows educators and learners to continue their learning sessions and feedback suggestions outside the domains of the classroom (Burbules, 2013; Cope \& Kalantzis, 2009). Learners can co-work with their classmates and contribute to the research, creation and final production of new knowledge once the face-toface sessions have finished (Kalantzis \& Cope, 2012). This dynamic process implies that higher education students are changing their behavior in order to cooperate and collaborate with peers using ubiquitous learning resources. Secondly, learners are able to participate in a variety of creative and motivational tasks that require the further revision and construction of received knowledge using communicative EFL and ubiquitous learning tools. Through the creation of new knowledge and the revision and reappropriation of existing knowledge, learners would be able to collaboratively create work that would be distinctive and motivating for the EFL team members (Burbules, 2004).

English communication is a growing necessity in today's society (Kennedy, 2012; Knapp, 2015). At the same time, learning in a ULE allows $21^{\text {st }}$ century 
learners to access valuable information and interact with others anywhere and anytime using a WI-FI connection, whenever necessary. Nowadays, being a ubiquitous learner implies carrying (or wearing) mobile devices that can facilitate continuous interaction with peers, experts, and other information sources. Increasingly, doing so effectively requires some mastery of English, the global language needed to foster professional communication and collaboration. With e-collaborative learning tasks, students can practice speaking the foreign language within the context or practical and professional concerns, and in so, be better prepared to use these skills in the workplace.

Different scholars have proposed different accounts of $21^{\text {st }}$ skills that involve learning to work with thinking tools, research, and the affordances of a digital life style as aspects of co-creation of knowledge (Trilling \& Fadel, 2009). Silva (2009), who added the term "ubiquitous" to describe $21^{\text {st }}$ century skills, has equally argued that what students can do with knowledge will be different each time and it is built by a team. In the past, learners were passively assessed for knowledge acquisition, usually on one occasion, at the end of their courses, via a test. Today the processes of multimodal knowledge building and learning interactions require different kinds of assessment within the context of learner-centered programs.

Living in the $21^{\text {st }}$ century involves the transformation of actions across our social, personal, professional and educational life (Tucker, 2014). According to McComas (2014), these $21^{\text {st }}$ century skills can be classified in six different types ranging from life skills to non-cognitive skills:

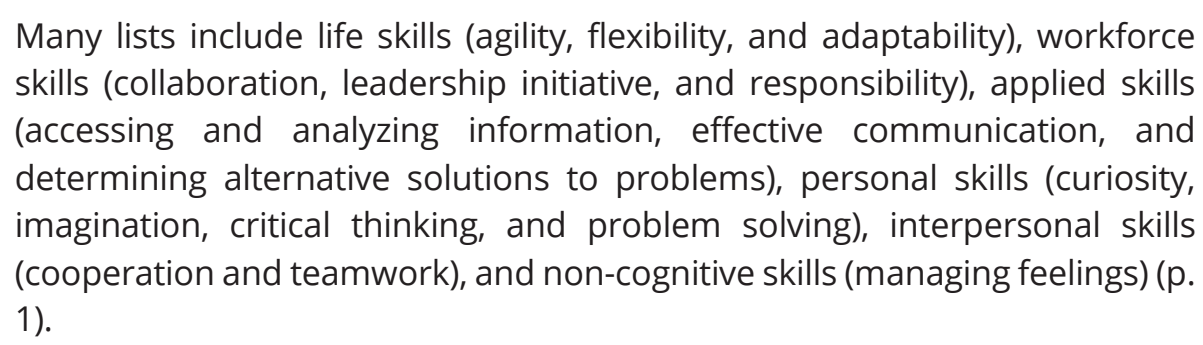

As we have mentioned, collaborative learning tasks that combine in-class with out-of-class interactions would help promote and enhance these $21^{\text {st }}$ century skills since learners would be learning to adapt to each other to form a team, to communicate their views and to find solutions to everyday professional and personal challenges. They would also have to be responsible with their individual role and its consequent outcome within the context of the group work. Finally, they would need to explore new possibilities for constructing meaning, working across group differences to connect diverse individual viewpoints within the context of a team perspective. All of these cognitive and 
non-cognitive skills will need to be exercised by team participants in pursuit of the collaborative task. As noted by Johnson and Johnson (1994), there is a necessary reorganisation of theory and skills when dealing with group activities. Correspondingly, it is essential that the collaborative task be designed with the intention of attracting the learners' interest so that they will be not only be engaged but motivated to improve their critical thinking and problem solving abilities.

A. L. Wang (2014) reported that there is a common misunderstanding between the terms "cooperation" and "collaboration" when applied to education. As Wang puts it: “Collaboration between partners needs to be well planned in advance and each individual has his or her mission to accomplish and a role to play" (p. 17). Cooperation does not require specific roles to be defined but the group participants contribute by sharing information and finding the solutions to the proposed task in equal terms. In a collaborative learning task, however, "the power structure [...] is hierarchical, and the entire team must work together toward a shared goal" (Wang, 2014, p. 17). Learners depend on each other during the process of teamwork in order to successfully accomplish the assignment, while in a cooperative exercise all, some, or just one participant will put the effort to complete the activity under the name of the group.

Nowadays, technology can successfully support learners in their learning process individually, cooperatively and collaboratively. Kalantzis and Cope (2012) used the notion of a "new knowledge society" to describe citizens who demand a new learning approach any day, anytime (24/7/365). Educators should consider promoting collaborative learning in both physical and digital environments so that interaction and teamwork can have some continuity outside the classroom hours. Accordingly, Egea (2007) argued that conversation, awareness, and coordination are three behaviours that happen in virtual collaboration, while Andreas et al. (2010) underlined that virtual collaboration positively expands the possibilities of face-to-face interactions and, therefore, communication. Given that e-collaborative learning tasks can be designed under a ubiquitous learning approach, it would be advisable to have some digital spaces for ubiquitous collaboration to take place, such as a VLE, a social network (Whatsapp, Facebook) or simply the traditional e-mail, for instance. Teachers must adjust the collaborative activities to the students' needs so that constructive interactions grow among the educational community. In this way, teachers' and students' attitudes, 
abilities and skills are constantly changing due to advances in ICTs. Dealing with $21^{\text {st }}$ century skills is about taking advantage of innovations in society, technologies and education (Tomei, 2013). This transformational education of the $21^{\text {st }}$ century entails an endless dialogue between teachers and learners, and with learning technologies.

\section{Methodology: Task examples and key concepts}

This section will provide some examples of collaborative and cooperative exercises designed during two consecutive years (2013-2015) in the compulsory subject of "English Applied to Social Work" (EASW from now on) in the Degree of Social Work at the Universidad de Las Palmas de Gran Canaria, Spain. This course combined the improvement of both EFL and ESP (English for Specific Purposes) skills at the intermediate level B1 of the Common European Framework of Reference for Languages (CEFRL). The course was designed following, first, a heuristic methodology for students to discover and experience participatory learning in class and online, and second, a ubiquitous task-based instruction having in mind the course content, ICT competences and the foreign communicative language skills students had to perform. A qualitative research approach was adopted by means of observations and by analyzing students' activities and the forum comments before and after the course.

Students were offered an outline designed for their learning process on the first day of the course. This learning plan included the course syllabus, the course competences, the individual tasks, the team work activities and the evaluation criteria with dates and summative percentages. Their evaluation was organized through the successful completion of individual exercises, collaborative oral tasks, e-cooperative activities, and a written test (See Table 1 for the classification of team exercises). This information was intentionally presented so that learners could understand that they were going to start working in a ULE in order to enhance communicative EFL skills.

\begin{tabular}{l|l}
\hline (e-)Collaborative tasks in small groups & E-cooperative exercises with the class \\
\hline Oral presentation & Wiki on phrasal verbs \\
\hline Video role-play & Glossary \\
\hline
\end{tabular}

Table 1. Classification of team exercises.

Students needed to know that their performance and participation were crucial to improve their EFL skills and to accomplish the course goals. Technology use was also implemented in the evaluation of the task design 
because it was suggested as another ability they would simultaneously enhance. Finally, after a few weeks, learners were asked to form groups of four members to respond to the two oral collaborative learning tasks of the course as it can be seen in Figure 1. These (e-) collaborative learning exercises were an academic oral presentation delivered in the class of any ESP topic in the field of social work, and a video role-play where a problem and a solution were created in the professional context of social workers. These two team activities needed both face-to-face and online communication, as it was explained in the assessment criteria. The procedure of these (e-) collaborative learning tasks implied that:

- EFL participants successfully created numerous ubiquitous learning activities under individual, peer to peer and collaborative learning techniques.

- Before starting the research, EFL/ESP learners chose their presentation topic based on the selection provided by the instructor.

- EFL/ESP learners structured the format of their presentation and organized the contributions of the team members themselves.

- The context creation and problem solution of the role-play highlighted the skills of EFL/ESP language competence and performance.

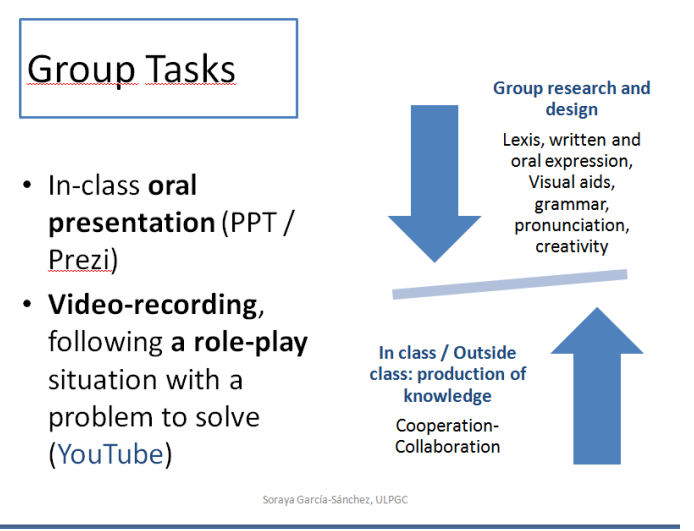

Figure 1. Oral collaborative tasks for EASW.

Moreover, two e-cooperative activities were proposed for students to share their work on the Moodle platform: a glossary and a wiki on phrasal verbs. With everyone's contribution, learners of EASW built an online glossary with generated definitions, the correct pronunciation, and examples of use in context, which they could either access from their mobile devices or print out for studying purposes. This online glossary was formed by the whole group of EASW learners. Another e-cooperative task was the wiki on phrasal verbs, which had two versions: one for the practical group A and another for the practical group B. Both wikis were visually open to everyone registered for the 
course. Learners belonging to group A or B had to create a sentence in context in the appropriate tense with a blank to allow the rest of the community to choose the right option from the four possible phrasal verbs given. It was a traditional multiple choice exercise produced by the students. The first section of the wiki compiled the sentences in context created by each participant before a deadline so that the instructor could mark them. The second part of the wiki included the whole set of sentences again with the right answer printed in bold as illustrated in Figure 2. The first example was provided as a model by the instructor.

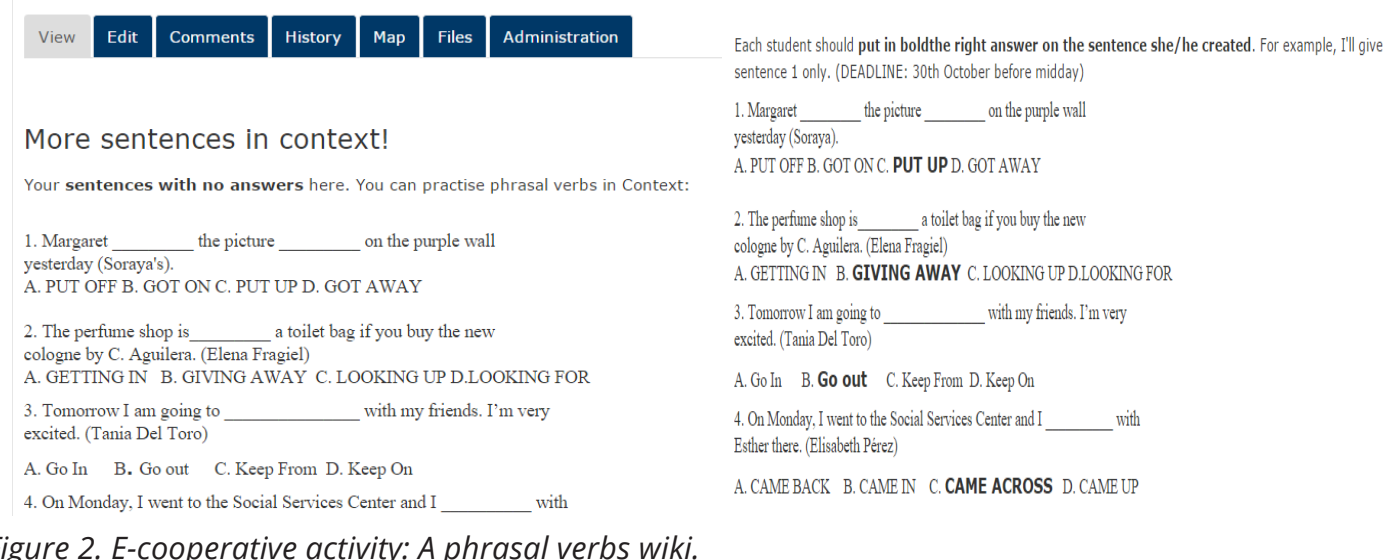

The purpose of these two e-cooperative tasks (the glossary and the wiki) was to activate the vocabulary of the course while students were in the production phase. By means of creating a democratically shared platform of pieces of information, students could learn from other definitions and examples, and revise the content of the course during the revision and learning reflection phases of EASW.

\section{Findings \& discussion}

The findings of this case study respond to the importance of improving an array of $21^{\text {st }}$ century skills by designing e-collaborative and e-cooperative learning tasks for EFL/ESP learners. The results show that students improved their communicative skills and their motivation by implementing ubiquitous team tasks. The two posts that initiated and concluded the course indicate that learners expected to improve their English communication skills and their vocabulary in the field of social work. As illustrated below, after having studied the answers on the "Expectations forum" (see Figure 3), the data suggest that although low in confidence, most learners (92\%) felt motivated to improve their English skills from the very beginning. 


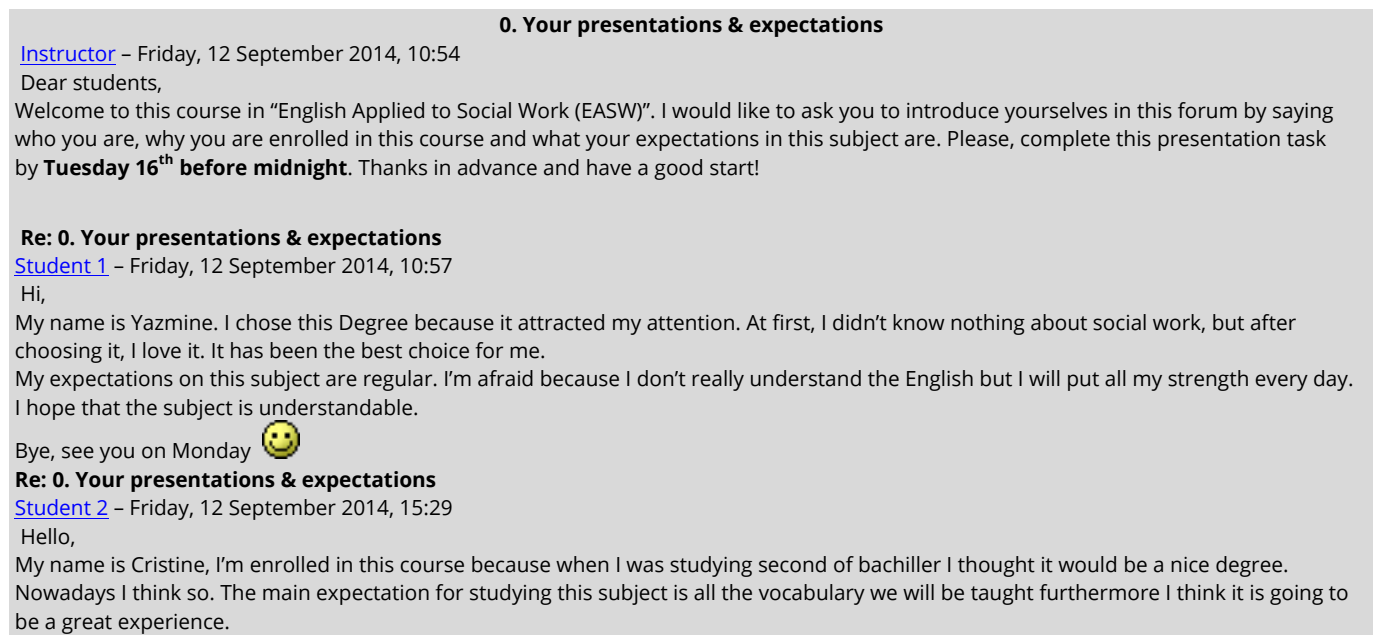

Figure 3. Sample answers extracted from the "Expectations forum".

The reflection forum entitled, "My weak and strong abilities today" (see Figure 4) was posted in either week 11 or 12 of the first semesters in order to invite EASW students to reflect on their learning progress. The responses encompass learners' positive attitudes with regards to learning English (92\%), and the importance of improving vocabulary applied to their professional context (98\%). Another common characteristic shared by the vast majority of learners is the challenge to speak in public successfully, convey their oral messages in English, and describe oral tasks in the foreign language, which for a considerable number (90\%) implied doing these communicative activities in English (level B1) for the very first time. In accordance with Dörnyei's and Kormos's report (2000), these manifestations support that the performance of an oral task grows due to different interrelationships of multiple variables including students' motivational attitudes. EFL learners of EASW had to face individual and team challenges of public speaking and context creation with the two collaborative learning tasks of the oral presentation and the representation of the video role-play. 


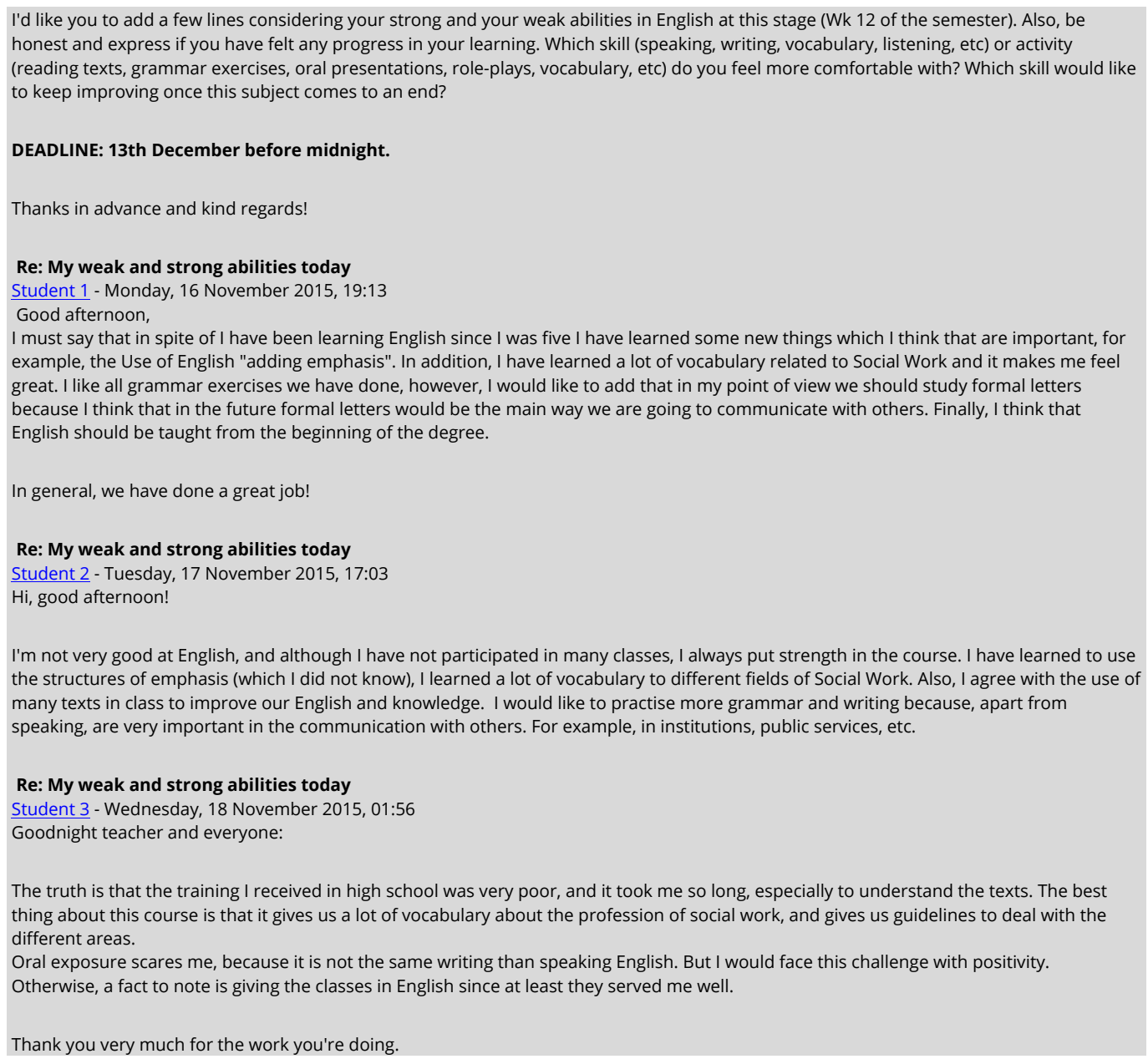

Figure 4. Sample answers extracted from the "Reflection forum".

When a ULE is implemented, communicative EFL competences together with the digital competence can be enhanced by not only accessing the internet but by creating, presenting, communicating and sharing students' knowledge inside and outside the classroom. The insightful contributions of students on the forums and the frequent interaction among learners draw attention to positive motivational attitudes improved in this study (Psotka, 2012). As Cohen (1994) suggested, successful collaboration would take place if the classroom is restructured around productive teams (Burbules, 2004). The findings propose that e-collaborative and e-cooperative tasks can be successfully designed along these dynamic lines in order to engage learners in active participation and continuous growth of their cognitive and non-cognitive EFL/ESP and $21^{\text {st }}$. century skills. 
Given that these results were similar during the two academic years of this study, the two collaborative oral tasks (Oral presentation \& Video role-play) seemed to have helped students improve their EFL/ESP verbal skills, considering how difficult it must have been for most learners to speak publicly not only in front of a large class of about 80-92 participants but also in a foreign language. This study could serve as an example for English language teachers to increase the number of creative collaborative and cooperative learning tasks that are intended to improve communicative skills. As Barson and Debski (1996) reported creativity can also be a positive outcome in foreign language learning when technology and assignments are goal-driven in a way learners control the product built.

Another notable outcome emerging from this research has to do with the importance of encouraging active learning so that active language skills are being developed within the context of practical use. By means of applying a ubiquitous task-based instructional approach (TBI) oriented to collaborative and digital tasks, learners participated in both formative and summative evaluations; their contributions and performance were part of the continuous assessment of the EASW program itself. This also entailed providing students with questions that allowed some space for conscious learning both individually and as teams. Figure 5 is an example of a video role-play and group positive feedback posted on the platform to share constructive remarks observed by these students.

Implementing e-collaboration and e-cooperation in EFL courses involves considering new evaluation methods such as the continuous assessment process, as promoted by the European Higher Education Area (EHEA). EASW students reported that they found it constructive to participate in their own self-assessment in order to improve their conscious learning skills. Peer to peer assessment exercises, on the contrary, were difficult to face since EFL learners felt that evaluating one another's work with regards to level B1 was beyond their abilities. They posted that they were not always aware of the implications of intermediate level B1 in English; perhaps more practical cognitive and metacognitive reflections should be added in future practice. This formative and summative assessment should recognize both the individual performance and team performance, either in class or online during different stages of the course (García-Sánchez, 2015). Rather than being only formative and summative, the evaluation of EASW was informative, interventionist, internet-based and interactive (Griffin, McGraw \& Care, 2012). 

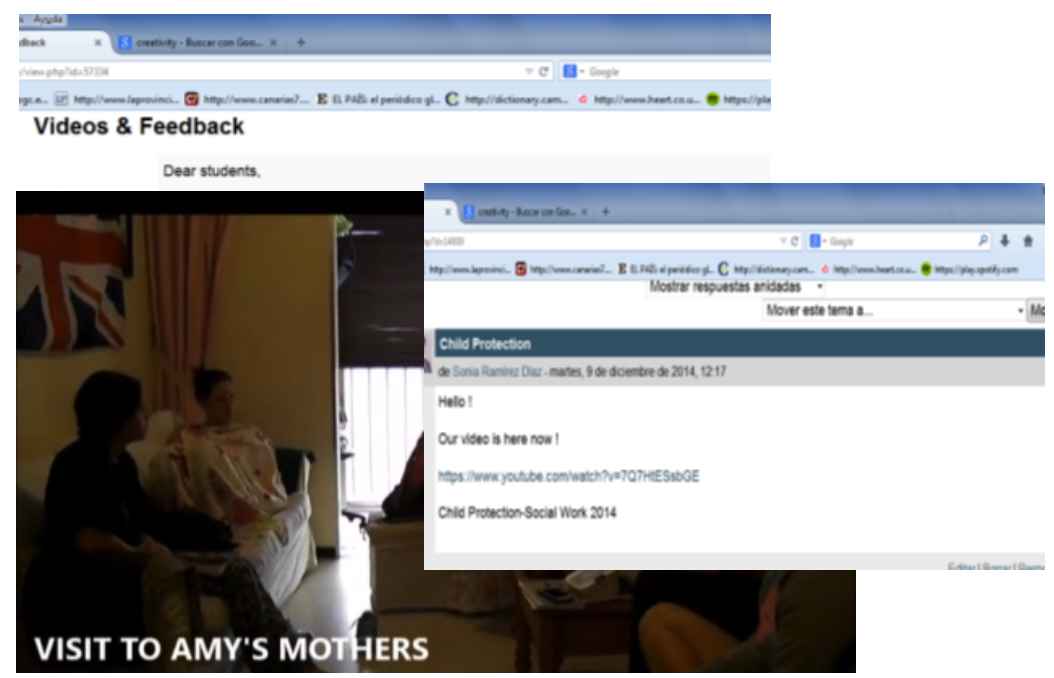

Figure 5. Example of video role-play and team e-feedback.

These results motivated the authors to conclude that the ubiquitous learning community of this study led to shared knowledge, thoughts, and resources by means of a variety of platforms and situations, which contributed to the enhancement of a range of $21^{\text {st }}$ century skills. Through e-cooperation and (e-) collaboration, students of EASW improved their communicative skills and their confidence in using a foreign language at intermediate level B1. Learners and teachers need to continue building their life-long learning identities so that they know where they are and what they aim to achieve in a specific time as creative input providers and as critical output recipients. Likewise, learners should carefully plan their learning tasks, and teachers should design adequate instructions, tools, resources and evaluation criteria that successfully support and help students meet the goals of teamwork (face-toface or online), and, through that, the performance of key competences.

\section{Conclusion}

This research has aimed to demonstrate that $21^{\text {st }}$ century skills should be added to higher education course programs to improve ICT abilities, teamwork, and communication. Technology can be effectively applied in the design of adequate communicative team tasks that can be successfully assessed. Collaborative learning that combines interactive learning technologies with face-to-face communicative exercises should put an emphasis on a dynamic, interactive approach that promotes problem-solving, communication and collaboration among the team members. Learners of the compulsory subject of English Applied to Social Work in the Degree of Social 
Work at the Universidad de Las Palmas de Gran Canaria actively participated in the performance of communicative learning skills in EFL/ESP based on an interactive ubiquitous learning environment that can happen anywhere and anytime (with or without mobile devices) to accomplish the designed tasks. The principal competences students achieved are:

- Creation of knowledge, context, and oral language discourse using ICT

- A high discourse potential for learners to explain themselves using EFL and ESP

- Performance and communication in EFL/ESP using the real language and a closer connection to their real life situations/professions

- Promotion of social interactions in class and online

At the same time, these learners have taken advantage of a continuous assessment that allowed them to improve their learning and reflect upon their achievements as individuals (autonomous learning) and as interdependent group members (collaborative learning). EFL communicative skills can be measured in both digitally and face-to-face mediums. English language educators should also consider using ULEs that can contribute to the performance of EFL communicative skills as well as other $21^{\text {st }}$ century skills. (E-) cooperative and (e-) collaborative tasks help to focus learners' attention on the aims of teamwork itself as well as the other course competences if the tasks are accordingly designed with these aims in mind.

There are numerous advantages at the present time in combining technology and learning activities with the intention of maintaining students' attention and engagement as well as increasing their abilities and motivation. Future studies could be focused on implementing more creative team tasks that contribute even further to enhancing interaction and coping with real life communicative situations among EFL and ESP learners in higher education. Comparative studies of different EFL/ESP Spanish regions would also provide a fruitful line for future research. We also believe that establishing a solid communicative learning approach in primary and secondary education would help Spanish higher education learners feel more confident about succeeding in their EFL discussions and, through this, to become the effective transnational European professionals needed by their society. The present research is driven by an intention to contribute to a lifelong learning philosophy that will help produce not only European Higher Education Area (EHEA) learners but global $21^{\text {st }}$ century citizens. 


\section{About the authors}

Dr. Soraya García-Sánchez is an English as Foreign Language teacher and researcher at the Universidad de Las Palmas de Gran Canaria, Spain. Some of her most recent research interests, which have been presented in articles and international conferences, are focused on gender, motivation, cultural and language input and ubiquitous learning for EFL/ESP university students. She has also created multimedia material for Open Access Platforms and published various self-study textbooks for EFL university students: Performing your Communicative Competence in English (with C. Luján-García), English Applied to Social Work, and English for Historians.

Dr. Nicholas C. Burbules is a Gutgsell Professor of Education at the University of Illinois at Urbana-Champaign, in the Department of Education Policy, Organization and Leadership. He is a nationally preeminent scholar in the field of philosophy of education and is internationally recognized for his work on the uses of information technology in education. His current research includes work related to ubiquitous learning, the impact of MOOCs and other technologies in higher education, and a virtue ethic of communication. He is frequently invited to lecture at universities around the world, and a number of his publications have been translated into other languages.

\section{Acknowledgements}

We would like to especially thank, Dr. Francisco Alonso Almeida, editor-inchief of the Journal Revista de Lenguas para Fines Especificos (LFE) for his valuable assistance during the edition of this special issue.

\section{LFE Article history}

Paper received: $03^{\text {rd }}$ January 2016

Paper received in revised form and accepted for publication: $8^{\text {th }}$ March 2016 


\section{References}

Andreas, K., Tsiatsos, T., Terzidou, T., \& Pomportsis, A. (2010). Fostering collaborative learning in Second Life: Metaphors and affordances. Computers and Education, 55(2), 603-615.

Burbules, N. C. (2004). Navigating the advantages and disadvantages of online pedagogy. In C. Haythornthwaite \& M. M. Kazmer (Eds.), Learning, Culture, and Community in Online Education: Research and Practice, (pp. 3-17). New York: Peter Lang.

Burbules, N. C. (2012). El aprendizaje ubicuo y el futuro de la enseñanza. Encounters, 13, 3-14.

Burbules, N. C. (2013). Los significados de 'aprendizaje ubicuo'. Revista de Política Educativa, 4, 11-19.

Burbules, N. C. (2014). El aprendizaje ubicuo: nuevos contextos, nuevos procesos. Revista Entramados: Educación y sociedad, 1(1), 131-135.

Cohen, E. (1994). Restructuring the classroom: Conditions for productive small groups. Review of Educational Research, 64(1), 1-35.

Cope, B., \& Kalantzis, M. (Eds.). (2009). Ubiquitous learning. Champaign. IL: University of Illinois press.

Dörnyei, Z., \& Kormos, J. (2000). The role of individual and social variables in oral task performance. Language Teaching Research, 4(3), 275-300.

Egea, K. (2007). Guided reflective practice for communication and collaboration: A tool for successful virtual teamwork. In P. Tseng, R. Kwang \& R. Fox (Eds.), Enhancing learning through technology (pp. 82-95). Singapore: World Scientific Publishing.

García-Sánchez, S. (2014). Knowledge creation and digital collaboration in higher education. In R. Rutherford (Ed.), Collaborative learning: Theory, strategies and educational benefits, (pp. 114). New York: Nova Science Publishers.

García-Sánchez, S. (2015). Dealing with ESP competences: Creativity and collaboration in higher education. The International Journal of Adult, Community and Professional Learning, 22(1), 1928.

Griffin, P., McGraw, B., \& Care, E. (Eds.) (2012). Assessment and teaching of twenty-first century skills. Netherlands: Springer.

Johnson, D.W. \& Johnson, R. (1994). Joining together: group theory and skills. Englewood Cliffs, New Jersey: Prentice Hall.

Kalantzis, M., \& Cope, B. (2012). New learning: Elements of a science of education. Cambridge: CUP.

Kennedy, C. (2012). ESP projects, English as a global language, and the challenge of change. Ibérica: Revista de la Asociación Europea de Lenguas para Fines Específicos (AELFE), (24), 43-54.

Knapp, K. (2015). English as an International lingua franca and the Teaching of Intercultural Communication. Journal of English as a Lingua Franca, 4(1), 173-189. 
Kim, C., \& Pekrun, R. (2014). Emotions and motivation in learning and performance. In J. M. Spector et al. (Eds.), Handbook of research on educational communications and technology (pp. 65-75). New York: Springer.

Liu, H. (2014). Assessing language anxiety in EFL students with varying degrees of motivation. Electronic Journal of Foreign Language Teaching, 11(2), 285-299.

McComas, W. F. (2014). $21^{\text {st }}$ century skills. In W. F. McComas (Ed.), The language of science education (p.1). Rotterdam: SensePublishers.

Ogata, H., \& Uosaki, N. (2012). A new trend of mobile and ubiquitous learning research: Towards enhancing ubiquitous learning experiences. International Journal of Mobile Learning and Organisation, 6(1), 64-78.

Peng, H., Su, Y. J., Chou, C., \& Tsai, C. C. (2009). Ubiquitous knowledge construction: Mobile learning re-defined and a conceptual framework. Innovations in Education and Teaching International, 46(2), 171-183.

Psotka, J. (2012). Interactive learning environments. In N. Seel (Ed.), Encyclopedia of the sciences of learning (pp. 1604-1606). Verlag Berlin Heidelberg: Springer.

Sears, D. A., \& Pai, H-H. (2013). Effects of cooperative versus individual study on learning and motivation after reward-removal. The Journal of Experimental Education, 80, 246-262.

Silva, E. (2009). Measuring skills for 21st-century learning. Phi Delta Kappan, 630-634.

Tomei, L. A. (2013). Top 10 technologies for designing 21st century instruction. International Journal of Information and Communication Technology Education, 9(3), 80-93.

Tucker, S. Y. (2014). Transforming pedagogies: Integrating 21st century skills and Web 2.0 technology. Turkish Online Journal of Distance Education, 15(1), 166-173.

Trilling, B., \& Fadel, C. (2009). 21st century skills: Learning for life in our times. John Wiley \& Sons.

Wang, A.-L. (2014). Key to developing cross-cultural collaboration: Three cases of collaborative projects. In S. Rutherford (Ed.), Collaborative learning: theory, strategies and educational benefits (pp.15-34). New York: Nova Science Publishers. 